\title{
Rechtsgeschichte
}

www.rg.mpg-de

http://www.rg-rechtsgeschichte.de/rg17

Zitiervorschlag: Rechtsgeschichte Rg 17 (2010)

$\operatorname{Rg} 172010 \quad 84-86$

http://dx.doi.org/10.12946/rg17/084-086

\section{Chung-Hun Kim}

Pilch's Perception of Law and Confucian

Normativity - Rethinking Customary Law in

Korean Historiography 


\section{Pilch's Perception of Law and Confucian Normativity - Rethinking Customary Law in Korean Historiography}

Pilch accurately describes the change in the notion of legal custom in the Early Middle Ages of Europe in German scholarship from "Gewohnheitsrecht « to "Rechtsgewohnheiten « or »Rechtsgewohnheit «. He even explores modern theories of law, e.g. »konkretes Ordnungsdenken ", and offers » Law = Violence - Violence* " as a conceptual formula to explain legal mechanisms in a culture determined by orality rather than literacy, where the idea of a law-making centralized state has not yet been established. Moreover, he inspires and encourages legal historians of all epochs to rethink their different notions and perceptions of law.

His remarkable research reminds scholars of Korean legal history of a recent and ongoing discussion about the correct notion of informal normativity in pre-modern ${ }^{\mathbf{I}}$ Korean legal culture. This article will show that similar questions such as those addressed in Pilch's research also arise from analyzing the origins of traditional Korean legal thoughts with regard to private disputes.

Since the beginning of the study of Korean legal history in the r960s until now, Korean legal historians have thought and taught that private disputes among individuals in traditional Korea, i.e. before the Japanese colonial rule in I9I0, were resolved through unwritten customary law: a customary law resulting from the principles of Confucianism and derived in Confucian village community compacts, ${ }^{2}$ and a customary family law of indigenous Korean origin. ${ }^{3}$ In brief, this "private law « is characterized by strong moral commitments to society as opposed to European individualism as in
Jhering's »Kampf ums Recht " or seen in " Michael Kohlhaas «. Korean customary law aimed to achieve and preserve the status of harmony and peace in accordance with Confucian morality and natural order. Koreans thought and still think that private disputes should not be resolved in court or by law. A mutual settlement was (and still is) always preferable in order not to disturb the order of peace and harmony. Korean scholars have quoted and drawn upon the work of German jurists, e.g. Eugen Ehrlich (»lebendes Recht «) and Fritz Kern (»gutes altes Recht $«$ ) in order to understand the legal order and thoughts of traditional Korea. ${ }^{4}$

Classical or pre-modern Korean legal historiography (»Chinese period «) ends with the activities of Japanese jurists during the colonial rule from I9I0 to I945 (»Japanese period «). Japanese jurists compiled Korean customs and formulated a collection of customs, ${ }^{5}$ on which Japanese judges could decide in newly implemented courts, and thus gradually assimilated Korean customs with the civil law in Japan. According to most current and elder Korean legal historians, the Japanese compilation lacks accuracy and completeness. They state that the Japanese compilers intentionally misinterpreted the idealistic Korean customary law in accordance with their policy of assimilation. For many years, when Korean legal historians said "customary law «, they meant to refer to the Confucian informal norms that were followed in Korea prior to the Japanese compilation.

Against this prevailing opinion, Marie Seong Hak Kim ${ }^{6}$ very clearly explains the interchangeable and indifferent use of the terms
I "Pre-modern " refers to the period before the modernization of Korea at the end of the I 9 th century. It is difficult to define a period in Korean history that corresponds exactly to the European Middle Ages because an established and relatively centralized state could be found in Korea since the 7 th century.

응

2 향약 in Korean, 師約 in classical Chinese characters; CHONGKO
CHor, Traditional Legal Thoughts in Korea, in: Journal of Korean Law 3/I (2003) 98.

3 Pyong-Ho PAK, Characteristics of Traditional Korean Law, Legal Systems of Korea, ed. by SHINYong Chun, Seoul I982, I3-34.

4 Chongko Choi, Law and Justice in Korea, Seoul 2005, 70-7I.

5 조선관습조사보고서/

朝鮮慣習調査報告書

(Choson Gwan Seup Josa Bogo- seu): Investigation report of Choson customs.

6 Marie Seong Hak Kim, Customary Law and Colonial Jurisprudence in Korea, in: American Journal of Comparative Law 57 (2009) 205-248; "Comparing the Incomparable «: Local Custom and Law in Sixteenth-Century Korea and France, in: Journal of Early Modern History I 2 (2008) 507-538; Law and Custom under 
»custom «, »traditional practice « and »customary law ${ }^{7} 7$ in pre-modern Korean legal culture. According to her research, a customary law did not exist in traditional Korea. What did exist before the Japanese compilation of customs, were just customs, which not reached any domain of law to constitute binding rules such as those that existed in Europe. She says that the Japanese jurists manufactured for the first time what most Korean legal historians today call Korean customary law. Her argument is that the Japanese jurists, based on the method of the German »Historische Rechtsschule «, tried to collect all available local customs of a nation in order to codify a universal civil law. However, the Japanese jurists could not find universal customs but diverse local usages. The difficulties of Japanese jurists in finding a customary law were obvious: where there is no customary law, no one can find any customary law.

But what did they find if not customary law? To find the answer to this question, Kim examines the origins of customary law in European legal history. In the context of the debate over Pilch's research, it is interesting how she methodologically approaches the material that lay before the Japanese jurists. She uses the method of comparative legal history and compares French "coutumes " of the Late Middle Ages and their compilation in the $15^{\text {th }}$ and 16 th centuries with the compiled material of customs of Choson. Astutely, she analyzes the origin of French private law rules and the function of customary law in the Middle Ages of Europe. By doing so, she sketches a Western model of customary law, which has the goal of defining the rights of individuals. Customary law was a popular means to form a set of rules in a local community. She continues, accurately noting that in European history, custom referred to the normative rules of behavior and the institutions that were given legal recognition by courts and were not only followed as a matter of practice but also enforced as a matter of law. There were two elements required for custom to obtain the force of law: the repetition by people of similar acts, anchored in time immemorial, and »opinio iuris seu necessitates ", or popular consent that transformed a habit into an imperative norm. Usage, even when it reflected the psychological element of will, did not constitute legal custom without opinio necessitatis, she states. Customary law was far from having a universal character, as it was necessarily limited only to the community where it originated. To become legal custom, the usage had to amount to the exercise of a right of those who practiced it.

After studying French »coutumes «, Kim argues for a rethinking of Korean terminology in legal historiography. With an understanding of both, the original European and Korean notion of legal custom, she argues that the unique and very different Korean customs were forced into a European model. In traditional Korea, in contrast, subjects did not seek to obtain a legally processed benefit. Customs in traditional Korea had the function of peace and social harmony as derived from Confucian principles. Although the Koryo (9I8-I392) and Choson (I392-I9IO) dynasties produced many codes, no regulations covering private disputes among subjects can be categorized. ${ }^{8}$

Furthermore, Kim argues that Korean customs or traditional practices never changed their status to the European term "customary law « because Koreans did not even think of law when having a private dispute. Filed lawsuits were merely complaints to the local magistrate informing him of moral misbehaviour of another person, requesting that the magistrate punish
Chosŏn Dynasty and Colonial Korea: A Comparative Perspective, in: Journal of Asian Studies 66/4 (November 2007) I067I097 with further references.

7 관습/慣習: Gwan Seup, 관행/慣行: Gwan Haeng, 관습법/慣習法: Gwan Seup Beop.

8 Most of the laws were based on government organization, a social status system, and criminal policy. Therefore, the Korean perception of law is an instrument of ruling, a means of controlling people, a sign of power of the reign over his subjects; it does not provide freedom and rights of the people like the Magna Carta. See PyongChoon Hahm, The Korean Political Tradition and Law, Royal Asiatic Society, Korea Branch, Monograph Series Number I, second edition I97I, I-84. 
him for not complying with Confucian mores and rites. They rather thought of morality and correct social behavior according to Confucian rules. In this sense, Kim's notion of customs matches Pilch's formula of law ${ }^{9}$ in order to keep social harmony and peace. In addition, the Confucian informal normativity can also be classified as thinking and living in orders similar to Pilch's research. ${ }^{\text {Io }}$

Unlike the current debate on Pilch's research, Marie Seong Hak Kim's treatises have not yet caused controversy or lively reaction among historians of Korean private law. In any case, it can be seen that conceptual clarity and rethinking of established notions of law is still to be achieved. Both Pilch and Kim contribute to the sensitization of terms, clarity of legal concepts and notions in legal history.

9 Pilch (20I0) 34.

io Pilch (2009) 460, 528.

Chung-Hun Kim 